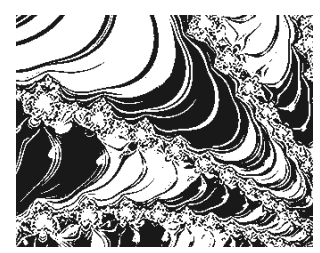

\title{
HAS THE ACCESSION \\ OF CROATIA TO THE EU \\ AFFECTED BUSINESS \\ SENTIMENT IN INDUSTRY? \\ SYNTHETIC CONTROL \\ METHOD APPROACH
}

Tihana ŠKRINJARIĆ, Mirjana ČIŽMEŠIJA

University of Zagreb, Faculty of Economics and Business, Zagreb, Croatia

UDK: 338.121(497.5:4-6EU)"2013"

Izvorni znanstveni rad

Primlieno: 13. 4. 2019.

Some economic and political events determine the level and dynamics of real economic variables on one hand, and business sentiment as a "soft" variable with a good predictive power for those variables, on the other. In this paper, we observe the impact Croatia's accession to the European Union (EU) in 2013 had on the Industrial confidence indicator $(\mathrm{ICl})$ as a measure of business sentiment in Croatia's industry. Entering the EU had a strong positive impact on the economies of countries that had joined the Union. Unlike other new EU member states, which entered the EU in an upward phase of the European business cycle, Croatia entered this community immediately after the stabilization of the European debt crisis and in a long period of recession. Using a novel application of the Synthetic Control Method (SCM) to the business survey (BS) data, the main hypothesis, that Croatia's accession to the EU had a strong positive impact on the $\mathrm{ICl}$ (which can be explained as euphoria), is confirmed. Conclusions derived from this research are a contribution to the improvement and popularization of BS and SCM.

Keywords: industrial confidence indicator, synthetic control method, business and consumer survey, counterfactual methodology

Tihana Škrinjarić, Faculty of Economics and Business, University of Zagreb, Trg J. F. Kennedyja 6,

10000 Zagreb, Croatia. 
The recent crisis in the European economy has demonstrated that macroeconomic models without latent psychological variables (such as assessments and expectations of economic agents) are not adequate enough, either for the explanation or for the prediction of extreme events like the economic downfall in 2008. One of them can be economic integration such as entry into the European Union (EU). At this moment, it is not enough to know the level and dynamics of macroeconomic variables. Equally important are the managers' and consumers' perceptions and expectations regarding these macroeconomic variables.

One of the milestones in the economic development of Croatia was its accession to the EU in July 2013. The EU can be presented as an advanced stage of economic integration (König, 2015), given the depth of the integration. Some characteristics of economic integration (Grgić \& Bilas, 2008) are the facilitation of financial flows and foreign investments through the establishment of investment and protection protocols, liberalization of labor movement within the Union, harmonization of legal regulation of the market for goods and services, harmonization of tax policy and macroeconomic policies, establishment of governing institutions, facilitation of integration and knowledge and technology transfers. It is obvious that there is a need to analyze changes in real macroeconomic variables caused by entering the EU. Of no less importance is examining whether entry into the EU has a significant impact on the economic sentiment, meaning on the managers' sentiment in different economic sectors and on the consumers' sentiment. Measuring the effects Croatia's accession to the EU had on business sentiment was the main research objective in this paper. The Business and Consumer survey (BCS) quantitatively expresses these "soft" variables and BCS results are useful in explaining this phenomenon since the outcome of these monthly confidence surveys constitutes an important part of economic information and provides reliable indicators for business sentiment.

The business survey (BS) deals with the managers' assessments and expectations about production trends in the recent past, with order books, the stocks of finished products, production expectations for the month, or the quarter, ahead, selling price expectations and so on. The managers' perception of the economic situation as a whole, expressed through the different variables in the survey, is an important signal in tracking and forecasting changes in the national, regional and global economic activity. Each variable in the BS, such as the expectation and composite indicators, can be a leading indi- 
DRUŠ. ISTRAŽ. ZAGREB GOD. 29 (2020), BR. 4, STR. 643-663

ŠKRINJARIĆ, T., ČIŽMEŠIJA, M.: HAS THE ACCESSION... cator for the corresponding variable. In accordance with the qualitative nature of the BS, it is of interest here to track only the direction of changes in a variable and in a referent series, namely industrial production. This is important since the BS data is usually available before the corresponding official statistic is published.

We try to measure the effects entering the EU had on the business sentiment in Croatia, by using the Synthetic Control Methodology (SCM) as a novel approach. Since the aforementioned indicators can be used in predicting macroeconomic variables for policymakers, significant changes such as EU entrance could affect the future movement of those variables as well. Moreover, forecasting could be enhanced with the information given by the SCM modelling results. Therefore, the results of applying this novel method in measuring the effects Croatia's accession to the EU had on a psychological variable such as business sentiment determine the importance of the research.

The SCM methodology is experiencing significant growth in its application in economics, and especially macroeconomics. It enables the researcher to obtain answers to the what-if scenarios and to measure the effects of events which affected an observed unit and to compare these effects to those units that did not experience the event. Based upon available data, the major event which could have affected Croatia's ICI was its entry into the European Union in 2013. That is why a hypothesis is formulated that this major event should have had a positive impact on Croatia's ICI after the entrance date, compared to what its value would have been if the EU accession had not happened. The contribution of the paper lies upon the application of the SCM methodology in this area of study, not only in Croatia but in Europe as well. Up until writing this research paper, the authors did not find any studies regarding confidence indicators and using SCM methodology to evaluate the intensity of some event (i.e. "treatment" in the SCM terminology) on them. The rest of the paper is structured as follows. The second section deals with the previous theoretical and empirical research results relevant to this study. Afterward, the third section depicts the methodology that was used in the fourth section, titled empirical research. The fifth and final section concludes the paper.

\section{LITERATURE REVIEW}

The referent series in the BS in the manufacturing industry is the year-on-year growth rate of industrial production. Many empirical results (Gayer \& Weiss, 2005; Čižmešija, 2001; Čižmešija et al., 2014; Kurnoga \& Čižmešija, 2015) show that ICI 
DRUŠ. ISTRAŽ. ZAGREB GOD. 29 (2020), BR. 4, STR. 643-663

ŠKRINJARIĆ, T., ČIŽMEŠIJA, M.: HAS THE ACCESSION... quarters ahead. It is important to point out that all BCS results are available on a monthly basis (in the last week of the reference month), while many real economic variables are officially published about once a month (or a quarter) later.

The ICI is usually used as a predictor of the direction of changes and it is not used only in industrial production. The role of ICI is also important in explaining and predicting changes in the overall economic activity. The importance of ICI in macroeconomics can be seen in many empirical analyses. The results and main conclusions of the latter are presented below. Demirel and Artan (2017) have analyzed the causality relationships between the confidence level and the fundamental macroeconomic indicators using a panel data analysis for 13 European Union countries for the period from 2000 to 2014. They found the bidirectional causality relationship between the level of confidence and consumption expenditures, as well as industrial production and inflation. A unidirectional relationship from the level of confidence to the unemployment rate and a unidirectional relationship from interest rates to the level of confidence was also detected. These results confirm the fact that economic confidence is a leading indicator in explaining the changes in most of the macroeconomic variables mentioned above. The relationship between business cycles of the V4 (Visegrád Four) countries and the confidence indicators in the industry were in the focus of empirical analyses conducted with the aim to find out the indicators' ability for monitoring business cycles. Tkacova et al. (2015) confirmed the assumption that these indicators (among others) can replace the GDP and that they are suitable for monitoring business cycles of the V4 countries.

Many other authors have included the ICI as a psychological "soft" variable in macroeconomic models (Arencibia Pareja et al., 2018; Badea et al., 2018; Simona, 2015; have included sentiment, perception and policy as the determinants of foreign direct investment in European developing countries). Nunes et al. (2014) empirically assessed the role of confidence in explaining Portuguese private consumption. The main conclusion in all the presented studies is that the ICI and all other confidence indicators derived from the BCS are very useful indicators in predicting the direction of changes (not the intensity of changes) in referent macroeconomic variables. The possibility of predicting Croatian recessionary episodes using probit models and including the ICI in models has been investigated and confirmed by Erjavec et al. (2016). It is not a novel idea in the international context that confidence indicators derived from the BCS can be used as leading indicators of economic activity. Nevertheless, the literature on the determinants of these kinds of psychological variables is quite silent. 
DRUŠ. ISTRAŽ. ZAGREB GOD. 29 (2020), BR. 4, STR. 643-663

ŠKRINJARIĆ, T., ČIŽMEŠIJA, M.: HAS THE ACCESSION...
What factors determine the value and the dynamics of business and consumer sentiment indicators? Are there any specific events that affect these variables? One of these events can be a country's integration into the EU.

Thus, Croatia's ICI is used in SCM in this paper. If we find that the entry into the EU had a significant effect on Croatia's ICI, this could open more room to explore other meaningful events and their effects on the ICI via SCM, and then indirectly on predicting changes in industrial production and in the whole national economy. Consequently, future research could expand the existing modes of forecasting macroeconomic variables with the information received from BCS and SCM results. Thus, the rest of the section focuses on empirical work regarding the SCM approach. We did not find any related research that focuses on business sentiment up until writing this research. However, the SCM methodology is being used more extensively over the last decade. The majority of the existing empirical research evaluates mostly the macroeconomic impacts of specific events, such as terrorism (Abadie \& Gardeazabal, 2003; Li, 2012; Yu \& Wang, 2013), research and education policy (Chan et al., 2014; Hinrichs, 2012), environment (Almer \& Winkler, 2017), political reforms (Duarte et al., 2014; Ribeiro et al., 2013), etc. Firpo and Possebom (2017) mentioned some other fields of application for SCM methods in international finance, economic and trade liberalization, labor, taxation and social connections and local development. EU accession has stimulated a new line of research and application of the SCM method in investigating the effects of that event on the macroeconomic variables. Campo et al. (2016) applied the SCM to 17 EU countries that entered the Union from the 1970s until 2004, in order to evaluate the impact that entering the EU had on growth and productivity. The main conclusion was that, on average, the per capita income would have been around $12 \%$ lower if the countries had not entered the EU. The only exception was Greece (the authors explain it via the too sudden opening up of the uncompetitive domestic industry). An important event that was shown to affect macroeconomic variables was the inclusion into the European Monetary Union (EMU). Gyoerk (2017) analyzed the effects of adopting the Euro within the EMU by focusing mostly on Sweden as a non-member of the EMU. The results indicated that Sweden would have a $10 \%$ lower labor productivity, exports, investment and consumption if it had entered the EMU. Similar research was provided for Slovakia, which had entered the EMU, in Žudel and Melioris (2016). The authors found that by adopting the Euro Slovakia gained a $10 \%$ increase of the GDP per capita. Positive gains were even realized 2 years before the formal adoption of the Euro due to anticipation effects. 
DRUŠ. ISTRAŽ. ZAGREB GOD. 29 (2020), BR. 4, STR. 643-663

ŠKRINJARIĆ, T., ČIŽMEŠIJA, M.: HAS THE ACCESSION...
As can be seen in the majority of cases, entering the EU had a strong positive impact on the economies that entered the union. It is important to know how the accession to the EU has affected real macroeconomic variables, but it is equally important to extract the impact entering the EU had on perceptions and expectations of economic actors concerning real macroeconomic variables such as the GDP, unemployment, prices, savings, inflation, etc. The increase of Croatia's ICI in 2013 and after that would probably still be present, but smaller than it was without the event of Croatia entering the EU. With Croatia's accession to the EU, there was gradual economic recovery. Croatia's imports and exports to the EU Member States increased and price growth slowed down. All of these facts have certainly influenced the growth of business sentiment in the manufacturing industry. This is especially important given the fact that the Croatian industry is highly dependent on the European economy. Managers were aware of all the benefits that would be gained by Croatia's accession to the $\mathrm{EU}$, and their optimism further contributed to the rise of the ICI, much more so than if Croatia had not joined the EU. There is a gap in the business sentiment research, since, to the knowledge of the authors, the effects of entering the EU have yet not been explored in the literature. Thus, the next sections deal with those questions.

\section{METHODOLOGY}

\section{Methodology description}

Most of the questions in the BS usually have three reply options: positive, neutral and negative. Relative frequencies (as percentages) have been calculated for each answer option. The common way of presenting BS data is balance. If $\mathrm{P}, \mathrm{E}$ and $\mathrm{M}$ denote percentages of the respondents' chosen options: positive, neutral and negative (respectively) with the sum equals 100 for each variable, the balance is a difference between $\mathrm{P}$ and $\mathrm{M}$, measured as percentage points of total answers. Balance is calculated for all questions (variables). Seasonally adjusted balance series are used to calculate composite indicators. So, with the aim to summarize the managers' subjective assessments of the economic variables, various indicators can be calculated with a continuous revision of their calculation. Confidence indicators are produced to reflect overall perceptions and expectations at the individual sector level in a one-dimensional index (European Commission, 2017). In this paper we use the ICI as a measure of managers' sentiment in the manufacturing industry. The ICI is a simple average of three variables: (1) order book, (2) production expectation and (3) stock of the finished products (with inverted sign). 
DRUŠ. ISTRAŽ. ZAGREB GOD. 29 (2020), BR. 4, STR. 643-663

ŠKRINJARIĆ, T., ČIŽMEŠIJA, M.: HAS THE ACCESSION...
The SCM was first developed in Abadie and Gardeazabal (2003) and Abadie et al. (2010, 2015). The goal is to evaluate treatment effects on a unit that experienced the treatment at a certain point of time, compared to the non-treated units. Without any loss of generality, we observe $J$ countries, with the first one being subjected to the treatment at date $T_{0}$ and the rest of $J-1$ are not. Denote with $y_{i, t}^{\mathrm{N}}$ the value of the outcome variable $i$ at date $t$, with $i \in\{1,2, \ldots, J\}$ and $t \in\{1,2, \ldots, T\}$ if the treatment did not occur. $y_{i, t}^{l}$ denotes the value of the outcome of variable $i$ at date $t$ if the treatment occurred at date $T_{0}$, where it holds that $1 \leq T_{0}<T$. It holds that $y_{i, t}^{i} \equiv y_{i, t}^{N}$ for $t \in\{1$, $\left.2, \ldots, T_{0}\right\}$ and every unit $i$. The effect of the treatment on the first unit has to be estimated as $\alpha_{1, t}=y_{\mathrm{i}, t}^{\mathrm{I}}-y_{\mathrm{i}, t}^{\mathrm{N}}$ for $t \in\left\{T_{0+1}, \cdots\right.$, $T$ \}, where the observed outcome can be written as follows:

$$
y_{1, t}=y_{i, t}^{\mathrm{N}}+\alpha_{i, t} D_{i, t}, D_{i, t}= \begin{cases}1, & \text { if } i=1 \text { and } t>T_{0} \\ 0, & \text { otherwise }\end{cases}
$$

$\alpha_{1, t}$ has to be estimated for dates $t \geq T_{0}$ and this is done by first estimating $y_{i, t}^{N}$ for the same dates. It is assumed that $y_{i}^{N}$ is generated via the factor model $y_{i}^{N}=\gamma_{t}+\theta_{t}^{\prime} Z_{i}+\lambda_{t}^{\prime} \mu_{i}+\varepsilon_{i}$, where $\gamma_{t}$ denotes the unknown common factor loadings, $Z_{i}$ vector of observed covariates not affected by the intervention (dimension $r$ ), $\theta_{t}$ vector of unknown parameters (dimension $r$ ), $\lambda_{t}$ is the vector of unobserved common factors (dimension $F$ ), with $\mu_{i}$ as a vector of unknown factor loadings (dimension $F$ ) and $\varepsilon_{i}$ is white noise vector. Let $W$ denote the vector of weights, with dimension $J-1$, where the weights $w_{i}$ are such that it holds $w_{i} \geq 0$ and $\Sigma_{i=2}^{\prime} w_{i}=1$. $K$ is a vector of linear combination coefficients before the intervention, with dimension $T_{0}$, such that it holds $\bar{y}_{i}^{K}=\sum_{s=1}^{T_{0}} k_{s} \bar{y}_{i, s}$. This linear combination is used to control for unobserved common factors in $\lambda_{t}$. Next, $X_{1}=$ $\left(Z_{1}^{\prime}, \bar{y}_{1}^{K_{1}}, \bar{y}_{1}^{K_{2}}, \ldots, \bar{y}_{1}^{K_{M}}\right)$ denotes the vector of pre-intervention characteristics of the first treated unit, with dimension $k=r+M$. $X_{0}$ denotes a matrix of dimension $k \cdot(J-1)$ which contains pre-intervention characteristics of the rest of the $J-1$ units.

The SCM has the goal to minimize the distance between the vector $X_{1}$ and the synthetic vector $X_{0} W$ in the following problem:

$$
\underset{W}{\arg \min }\left\|X_{1}-X_{0} W\right\|_{V} \text { s.t. } w_{i} \geq 0 \text { and } \sum_{i=2}^{J} w_{i}=1
$$

where $\mathrm{V}$ is the distance matrix of order $k$. The usual approach is to solve (2) in two steps. First, an inner problem is solved to find $V^{*}$ and in the second step the $W\left(V^{*}\right)$ is found in order to minimize the mean squared error of the expected value of $X_{1}-X_{0} W^{*}$. 
DRUŠ. ISTRAŽ. ZAGREB GOD. 29 (2020), BR. 4, STR. 643-663

ŠKRINJARIĆ, T., ČIŽMEŠIJA, M.: HAS THE ACCESSION...
Regarding the inference of this methodology, it has been in discussion and development for the last 3-4 years. The first group of papers that are linked to the original Abadie and Gardeazabal (2003) and Abadie et al. (2010, 2015) papers, mostly focused on graphical representations of the estimated results. These were called the placebo tests, in which every unit that was in the donor pool ( $J-1$ units) is observed as the treated unit and the optimization of (2) is repeated $J-1$ times and the treatment effects are graphically observed (in-place placebo test) in order to see whether great difference exists between the treated unit (the first one) and the rest of the units in the analysis. Based upon these results, the null hypothesis of no treatment effect on the treated unit can be tested by calculating the $p$-value for every period $t$ after the treatment:

$$
p-v=P\left(\left|\hat{\alpha}_{j, t}^{p l}\right| \geq \hat{\alpha}_{1, t}\right)=\frac{\sum_{j \neq 1} 1\left(\left|\hat{\alpha}_{j, t}\right| \geq \hat{\alpha}_{1, t}\right)}{J-1}
$$

where $\hat{\alpha}_{j, t}^{p l}$ denotes the effect of the treatment on the remaining $J-1$ units and 1(-) being the indicator function. There is no assumption on the distribution of the error term in the model, due to this test being a nonparametric one. Confidence intervals for the treatment effect can be estimated as well from the $p$-values in (3). Since not all treatment effects have to differ in every period for the first unit (values of $\hat{\alpha}_{1, t}$ ), Firpo and Possebom (2017) suggest calculating p-values for dates after the treatment as follows:

$$
p-v=P\left(r M S E_{j, t}^{p l} \geq r M S E_{j, t}\right),
$$

where $r M S E_{j, t}^{p l}$ is the ratio of the MSE (mean squared error) after and before the treatment for $J-1$ units (donor pool) and $r M S E_{j, t}$ being the ratio for the treated unit. For more details, please see Ando and Savje (2013), Ferman and Pinto (2017a, 2017b), Ferman et al. (2017), Galiani and Quistorff (2017), Imbens and Rubin (2015).

\section{Data description}

To evaluate if entering the EU has affected the sentiment in Croatia's industry, the following data was collected from Eurostat (2018) and the European Commission (2018). Quarterly data ranged from 2008Q2 until 2017Q4. The quarterly ICI data were collected based on the monthly values of ICI (as originally presented by the European Commission). The details are provided in Table $1 .^{1}$ The following countries along with Croatia are included: Romania, Bulgaria, Slovenia, Slovakia, Poland, Malta, Hungary, Latvia, Lithuania, Estonia, the Czech Republic and Cyprus. These countries were chosen based upon 
DRUŠ. ISTRAŽ. ZAGREB GOD. 29 (2020), BR. 4, STR. 643-663

ŠKRINJARIĆ, T., ČIŽMEŠIJA, M.: HAS THE ACCESSION...

(1) TABLE 1

Data description the donor pool the economies of which have similar characteristics as the economy of the treated unit. According to the World Bank classification from 2016, all these countries are in the same income group (high income), with the exception of Bulgaria and Romania (which belong to the upper-middle group). Moreover, the majority of these countries belong to the CEE group. Thus, it is reasonable to use them as the donor pool in the analysis. However, in our research, these countries did not undergo the "treatment" of entering the EU in 2013. The variables used in the study are justified via the calculation of the ICI index based upon questions from the polls regarding the industry climate. Furthermore, we include variables in accordance with data availability. For example, the expected production variable was not available in official statistics, thus it was not possible to include it in the study.

Variable / Description

EMP Total employment in industry; Quarterly time series $(2015=100)$, from 2008Q2 to 2017Q4. Source: Eurostat. https://ec.europa.eu/eurostat/web/products-datasets/-/teiis400 [accessed June 1st (2018)];

IIP Index of industrial production; Quarterly time series $(2015=100)$, from 2008Q2 to 2017Q4. Source: Eurostat. https://ec.europa.eu/eurostat/web/products-datasets/-/sts_inpr_m [accessed June 1st (2018)];

PPID Domestic output price index; Quarterly time series $(2015=100)$, from 2008Q2 to 2017Q4. Source: Eurostat. https://ec.europa.eu/eurostat/web/products-datasets/-/sts_inppd_m [accessed June 1st (2018)];

PPIN Non-domestic output price index; Quarterly time series $(2015=100)$, from 2008Q2 to 2017Q4.

Source: Eurostat. https://ec.europa.eu/eurostat/web/products-datasets/product?code=sts_ inppnd_m [accessed June 1st (2018)];

ICI Industry confidence indicator; Quarterly time series $(2015=100)$, from 2008Q2 to 2017Q4. Source: Eurostat. https://ec.europa.eu/info/business-economy-euro/indicators-statistics/ economic-databases/-business-and-consumer-surveys/download-business-and-consumersurvey-data/time-series_en (ICI) [accessed June 1st (2018)].

Source: Eurostat (2018)

\section{EMPIRICAL RESULTS}

Empirical results are presented in two parts. After the initial results, in order to calculate the synthetic ICI, the model robustness checking is performed in the second subsection.

\section{Initial results}

Since Croatia joined the EU on July 1st 2013, the third quarter of 2013 is assumed to be the treatment date. The SCM model was optimized for the period 2008Q2 -2013Q2, where the Croatian ICI is assumed to be the treated output variable, and 
DRUŠ. ISTRAŽ. ZAGREB GOD. 29 (2020), BR. 4, STR. 643-663

ŠKRINJARIĆ, T., ČIŽMEŠIJA, M.:

HAS THE ACCESSION..

$\rightarrow$ TABLE 2

Results from the optimization problem of model (3)

TABLE 3

Weights of countries in Croatian synthetic $\mathrm{ICl}$
IIP, EMP, PPID and PPIN were the control variables. The optimal value of variable weights was chosen based upon minimizing the MSE in the pre-treatment period. The basic results of the optimization problem are given in Table 2 and individual country weights are shown in Table 3 . The average values of the predictor variables for the real ICI and synthetic ICI in Croatia in the pre-treatment period were very close, with the biggest difference in the IIP value. In the optimization problem, the employment variable had the biggest weight in the calculation of the synthetic ICI, with $77.6 \%$. The second variable was IIP (with 12.3\%) and the price indices had the smallest weights $(7.5 \%$ and $2.6 \%)$. From this it can be said that employment is the variable which mostly affects the obtained results. Table 3 depicts the weights of the countries in the synthetic ICI variable. It is evident that the majority of the weights belong to Lithuania (46.1\%), Cyprus $(28.9 \%)$ and Bulgaria (20.1\%).

\begin{tabular}{lrrr}
\hline Average & Treated ICI & Synthetic ICI & $V^{*}$ \\
\hline Employment & 103.30 & 103.74 & 0.776 \\
IIP & 103.10 & 97.23 & 0.123 \\
PPID & 100.55 & 100.37 & 0.075 \\
PPIN & 101.60 & 104.05 & 0.026 \\
MSPE & & 7.97 & \\
\hline
\end{tabular}

Note: MSPE denotes mean squared prediction error. $V^{*}$ denotes optimal weights for the variables.

\begin{tabular}{lc}
\hline Country & $w^{*}$ \\
\hline Romania & 0.005 \\
Bulgaria & 0.201 \\
Slovenia & 0.006 \\
Slovakia & 0.000 \\
Poland & 0.005 \\
Malta & 0.018 \\
Hungary & 0.003 \\
Latvia & 0.005 \\
Lithuania & 0.461 \\
Estonia & 0.007 \\
Czech Republic & 0.000 \\
Cyprus & 0.289
\end{tabular}

Note: $w^{*}$ denotes optimal values of the weights for each country in the analysis.

Next, we observe the values of the real ICI and synthetic ICI for Croatia based upon optimization results of the SCM 
DRUŠ. ISTRAŽ. ZAGREB GOD. 29 (2020), BR. 4, STR. 643-663

ŠKRINJARIĆ, T., ČIŽMEŠIJA, M.:

HAS THE ACCESSION...
FIGURE 1

Values of the real and synthetic Croatian ICl
FIGURE 2

Difference between the real and synthetic Croatian ICl model, and the values are shown in Figure 1. The vertical line represents the time when entry into the EU occurred. While it can be seen that the values of the real and synthetic ICI were coinciding almost throughout the whole pre-treatment period, the two curves diverge one from another after the treatment. Moreover, the value of the real ICI was on a higher level in the whole post-treatment period. This means that the accession to the EU has positively affected business sentiment in Croatia. Managers in Croatia's industrial production have seen the country's entry into the EU as a new chance to expand their production and exports, as well as new opportunities to employ new people due to the possibilities of greater demand. Thus, it was reflected in the ICI being greater than if Croatia had not entered the EU (synthetic value). The differences between the two series are shown in Figure 2 .

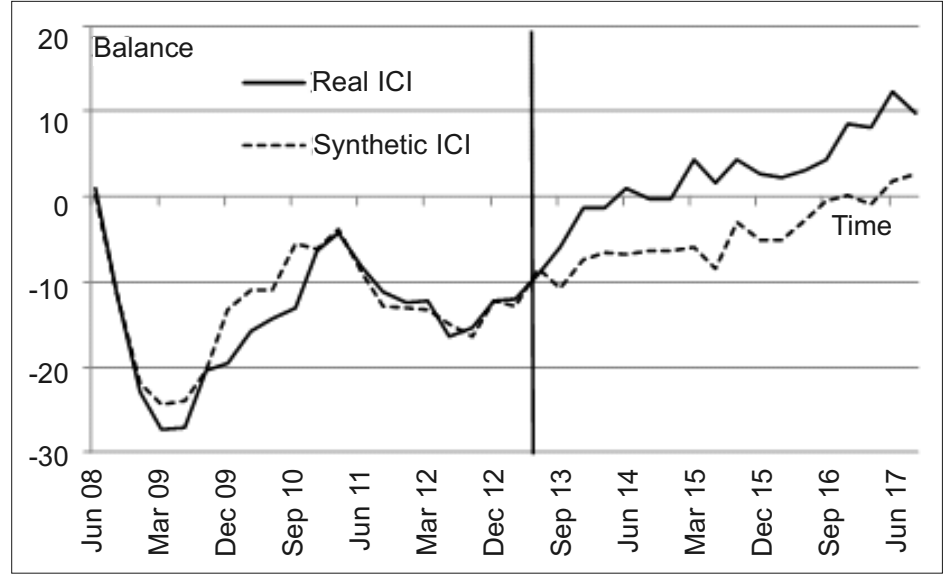

Note: Vertical line in all figures represents the mark when the treatment is assumed to occur.

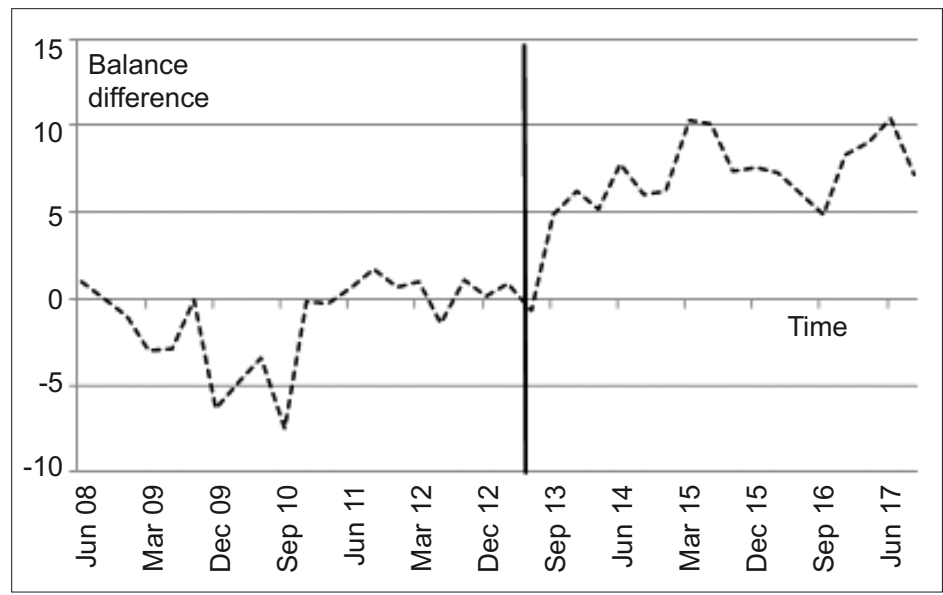




\section{Model robustness check}

Moreover, the placebo test was carried out in to explore the significance of the effect of the treatment. Each country was assumed to be the treated one; the SCM model was re-evaluated and the synthetic ICIs were calculated for all countries in the sample. Synthetic ICIs are shown in Figure 3, where Croatia's ICI is marked with a black and bold line for better comparison. Figure 4 represents the gaps of the placebo test, with the aim of comparing the treated effect of Croatia to other countries. If the treatment had a significant effect, Abadie et al. (2010) concluded that it should have been visible on a graphical representation of the empirical distribution of gaps, such as in Figure 4. Based on the analysis in the mentioned study, it can also be concluded here that the gap for Croatia is the most unusual one compared to others. The reasoning is that it is greater than all the gaps in the majority of the posttreatment period.

2 FIGURE 3

Placebo test, the $\mathrm{ICl}$ for each country in the analysis

\section{- FIGURE 4}

Placebo test, gap levels for each country in the analysis

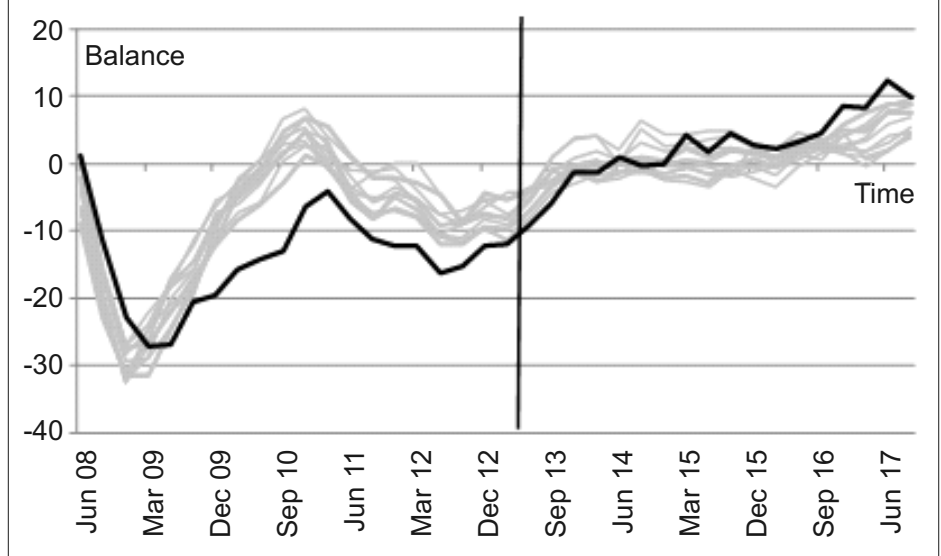

Note: Black bolded line represents the ICI for Croatia.

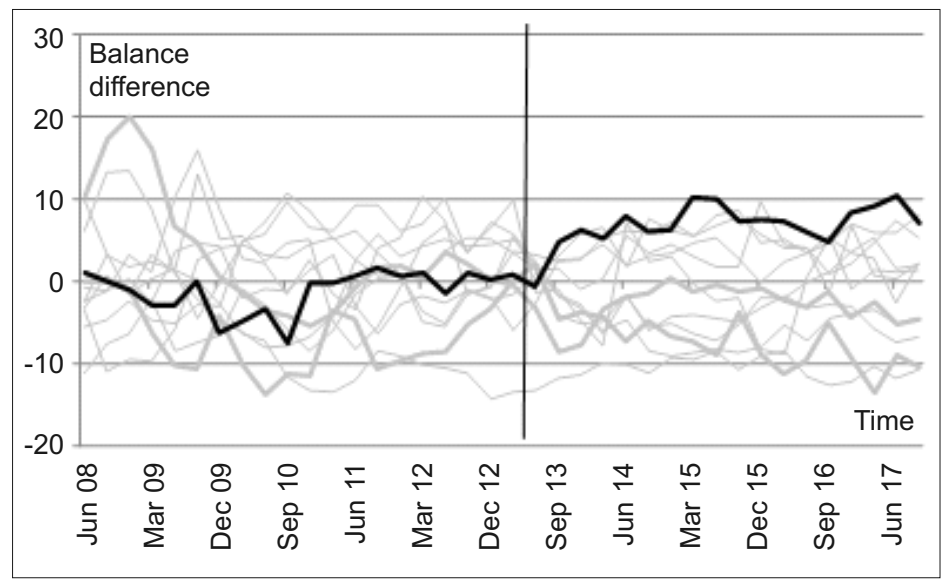

Note: Black bolded line represents the treatment values for Croatia. 
DRUŠ. ISTRAŽ. ZAGREB GOD. 29 (2020), BR. 4, STR. 643-663

ŠKRINJARIĆ, T., ČIŽMEŠIJA, M.: HAS THE ACCESSION...

๑ FIGURE 5

Comparison of Croatia's real and synthetic $\mathrm{ICl}, 95 \%$ confidence interval
Since the inference in SCM methodology has in recent years been in the process of development, we have calculated some basics as follows. First, we calculated $p$-values for the test of no significant effects of entry into the EU for each period after entry. In the second step, we calculated confidence intervals for the synthetic ICI of Croatia, with the assumption of the normal distribution and by following steps in Altman and Bland (2011) and Gardner and Altman (1986). More insights can be provided on the difference between the real and synthetic ICI over time. The $95 \%$ confidence interval is shown in Figure 5.

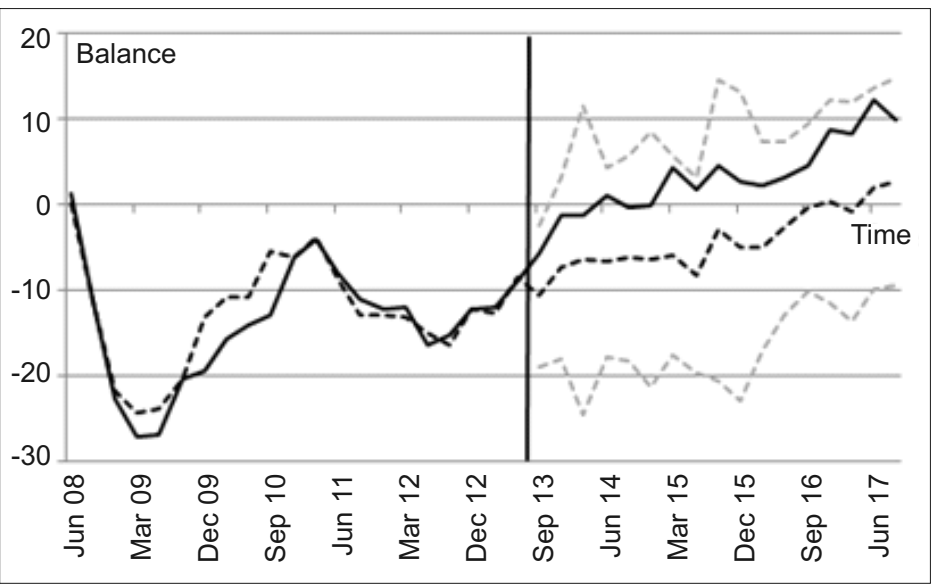

Note: Grey dashed lines represent the upper and lower bands of the 95\% confidence interval. Full black line denotes true ICI, black dashed line denotes the synthetic ICI.

It seems that the real ICI does not exceed the upper bound of the $95 \% \mathrm{CI}$, meaning that the difference between the two curves is not significant. This could mean that the euphoria experienced by the businesses which underwent the polls for the ICI calculation induced by entry into the EU was not that impactful. However, as Firpo and Possebom (2017) state that the treatment effects do not have to be very different in every period, it is better to calculate $p$-values based upon the RMSE (root mean squared error) values. Thus, we follow the procedure in the mentioned paper and calculate the modified MSE ratios, the $p$-values and confidence intervals based upon Firpo and Possebom's (2017) procedure. The estimated 92.31\% confidence interval is shown in Figure 6. Since the calculation of the confidence interval is based upon the permutation test, the levels of statistical significance values can take a discrete number of values. Thus, we choose $1 / 13$, as it is closest to the 95\% confidence interval in Figure $5 .^{2}$ Here, we can see that 
DRUŠ. ISTRAŽ. ZAGREB GOD. 29 (2020), BR. 4, STR. 643-663

ŠKRINJARIĆ, T., ČIŽMEŠIJA, M.:

HAS THE ACCESSION..
Э FIGURE 6 Comparison of Croatia's real and synthetic ICl, 92.31\% confidence interval bands calculated as in Firpo and Possebom (2017) the values of real ICI surpass the upper bound right after entry into the EU and stay outside the confidence interval for almost half of the post-intervention period. Thus, entering the EU had a significant impact on the business sentiment in Croatia. Finally, to confirm the robustness of results, we test the null hypothesis of no treatment effects for Croatia via the permutation test and $p$-value based upon the MSE ratios for every country in the sample. The $p$-value is nearly equal to zero, which rejects the null hypothesis of no treatment effects. Moreover, we perform a standard $t$-test of mean differences between two paired samples, for the real and synthetic ICI in Croatia. The empirical test value rejects the null hypothesis (the two-sample $t$-test showed that the difference between the mean of the real ICI and the synthetic ICI is highly significant, $t(17)=16.68, p$-value $<0.01)$. This reconfirms the results presented in Figure 6; i.e. that joining the EU had a significant positive impact on business sentiment in Croatia.

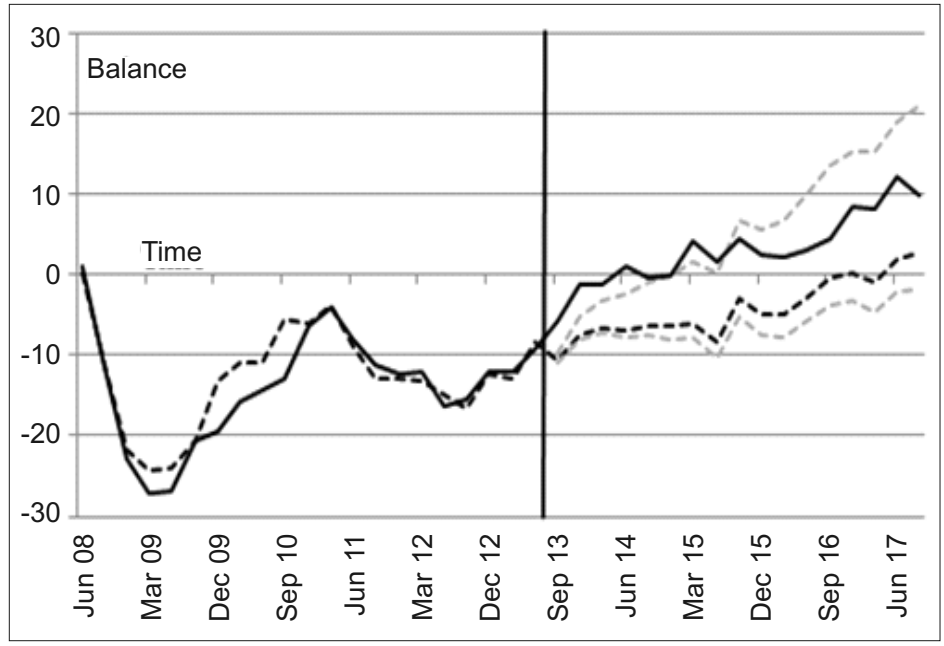

Note: Grey dashed lines represent the upper and lower bands of the 92.31\% confidence interval. Full black line denotes the real ICI, black dashed line denotes the synthetic ICI.

Finally, a time placebo test was performed to evaluate if the confidence indicator was under the influence of entry into the EU before the formal date of entry. Thus, we chose: (i) one quarter prior and (ii) two quarters prior to entry into the EU so as to evaluate the whole procedure once again. First of all, the MSPEs (mean squared prediction errors) for both tests are bigger compared to the MSPE of our first model (they are 10.12 and 12.75 respectively). This means that the first model estimated the differences between the real and 
DRUŠ. ISTRAŽ. ZAGREB GOD. 29 (2020), BR. 4, STR. 643-663

ŠKRINJARIĆ, T., ČIŽMEŠIJA, M.:

HAS THE ACCESSION...

\section{FIGURE 7}

Placebo in time, one quarter before EU
FIGURE 8 Placebo in time, two quarters before entry into the EU synthetic ICI to be minimal before entry into the EU. Next, the $92.31 \%$ confidence interval was calculated as presented previously in Figure 6, and as shown in Figures 7 and 8.
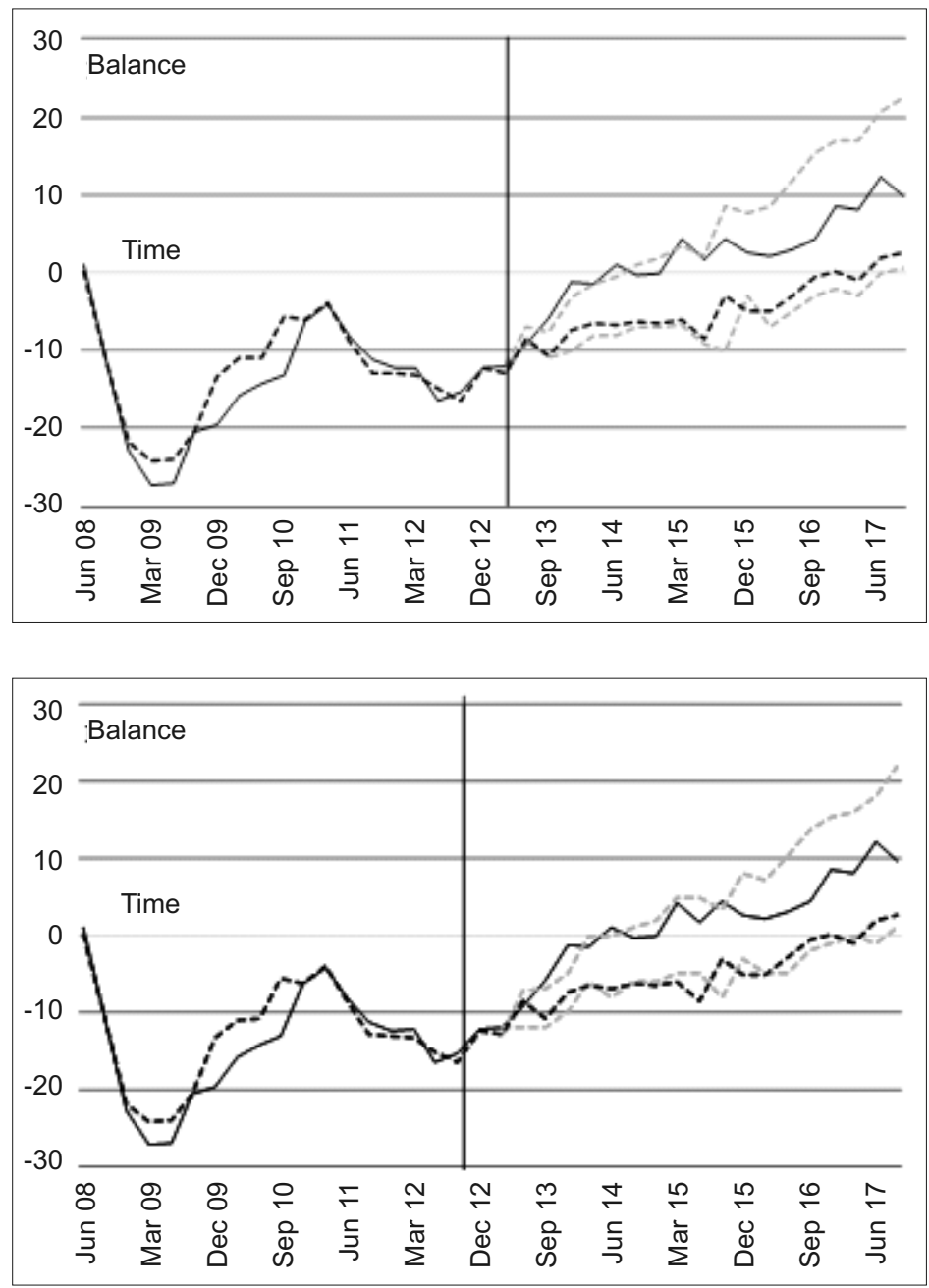

It is evident that the effects in Figure 7 are somewhat significant for 3-4 quarters, but quickly the effects become insignificant. The insignificance of the results is even more visible in Figure 8, where the real ICI is within the $92.31 \%$ confidence interval almost all of the time. This can be interpreted in the way that the formal date of entering the EU had the biggest psychological impact on managers in Croatia. Finally, based upon empirical analysis, it can be concluded that the accession of Croatia to the EU could affect business sentiment in Croatia. The optimism was greater as Croatia was entering the EU, compared to the counterfactual that it did not happen. 
In this research, we wanted to test the significant impact of Croatia's entry into the EU (as an important event in economic and political terms) on the business sentiment in Croatia's industry. The main results indicate that if Croatia had not entered the EU, the sentiment, measured by ICI would have been lower. This means that entering the EU had a euphoric effect on the sentiment and expectations of Croatia's managers in industrial production. The cumulative effect has grown over time, meaning that there is some persistence in the sentiment even at the end of the observed period. However, this could diminish if the managers do not take opportunities that are now more accessible to them in an enlarged market.

When comparing the results of this research to previous studies which have been investigating the relationship and synchronization of business cycles of European countries, several conclusions arise. Kovačić and Vilotić (2017) found statistically significant concordance indices (business cycle synchronization measures) between Croatia and Cyprus, France, Finland, Germany, Iceland, Italy, Lithuania, Latvia, Slovakia, Slovenia, Spain and Turkey. Thus, Lithuania and Cyprus are rationalized here as having their business cycles fairly synchronized with the Croatian business cycle. Koukouritakis et al. (2013) found that Croatia, alongside Bulgaria, Cyprus, Greece, Romania and Slovenia, is interdependent regarding its responses to Euro zone macroeconomic policy changes. Kurnoga Živadinović et al. (2009) utilized cluster analysis for the GDP per capita, total employment rate and comparative price levels in order to group European countries based upon the similarities within clusters. The authors found two distinct clusters. Croatia belonged to the cluster consisting of Belgium, France, Italy, Greece, the Czech Republic, Poland, Slovakia, Romania, Bulgaria, Spain, Estonia, Latvia, Lithuania, Cyprus, Portugal and Slovenia. Thus, Croatia was in the same cluster as Bulgaria, Cyprus and Lithuania, when comparing these countries by the mentioned variables. Moreover, Tomić and Demanuele (2017) focused on the new EU member states and compared business cycle coherence between them and Croatia in the period from 1995Q1 until 2014Q3. The results of this study indicate that Croatia was in significant synchrony with the rest of the observed countries: Cyprus, Estonia, Latvia, Lithuania, Malta, Slovakia and Slovenia.

Several factors influenced Croatia's economic growth after 2013. One of them is the accession to the EU. Macroeconomic stabilization, export growth, freedom of movement in the single market, which for many Croatians means they can 
DRUŠ. ISTRAŽ. ZAGREB GOD. 29 (2020), BR. 4, STR. 643-663

ŠKRINJARIĆ, T., ČIŽMEŠIJA, M.: HAS THE ACCESSION... live, work and study in other EU member states, have happened. Many business opportunities have opened for business subjects. During the period of Croatia's gradual exit from recession, the accession to the EU has additionally strongly influenced the increase in managerial optimism in the manufacturing industry. The SCM method has just confirmed this fact.

Since it was shown in the previous section that entering the EU had a meaningful impact on the sentiment in Croatia, it could be concluded that models in which the sentiment variables are used should be corrected with such information. Moreover, other relevant events should be usually tested for presence in the sentiment so as to obtain better fitting results. Thus, future work should focus not only on testing the presence of effects of political, economic and other events, but also on estimating (macro)economic models in which sentiment is included. Furthermore, since the business sentiment was found to be affected by entering the EU, other sentiments could be affected as well. Other countries that were used here in the donor pool for the observed period could be compared in future work in order to get insights into the differences between them and to search for sources of differences if they exist. Namely, some of the countries did not experience significant changes in their sentiment after entering the EU. The moderate increase as seen in Croatia (2013 entrance) was observed for Malta and Cyprus (2004 entrance). Since the methodology used in this study only confirms the significance of some effects, the comparison is out of reach of this work. That is why we will focus more on trying to find the sources of changes in the ICI for different countries. Especially since, even today when the hot topic is Brexit, the e.g. consumer sentiment is getting higher despite all the political uncertainty (see Verdict, 2018).

Some of the pitfalls of the study were as follows. Data availability is often a problem in empirical research. This is true for this paper as well. Some variables could not be included in the analysis due to the lack of a meaningful time span to be included in the analysis. This provides incentives for future work to collect longer time spans and to replicate this study in order to have additional checking of the robustness of results. Since the results indicate significant changes in the business sentiment, this could potentially have an impact on including the ICI indicator into economic modelling. Moreover, other meaningful events could be explored in future work as well. The intention is to extend this study on other sentiment indicators (in retail trade, in construction, in the services sector and in the whole economy) to evaluate the impact of other meaningful economic and political events. This means that, when the economy expects (anticipates) major events in 
DRUŠ. ISTRAŽ. ZAGREB GOD. 29 (2020), BR. 4, STR. 643-663

ŠKRINJARIĆ, T., ČIŽMEŠIJA, M.: HAS THE ACCESSION... the future regarding different aspects of itself, the SCM methodology can be applied to foreshadow future movements of relevant variables. Furthermore, future work is going to compare the results from this study to other countries that entered the EU in the last 15 years with the purpose of obtaining information for future possible extensions of the EU. Thus, other candidate countries can get insights into possible movements of the sentiment right after entering the EU and can adjust to the most likely changes.

\section{NOTES}

\section{REFERENCES}

${ }^{1}$ The used R codes are available at: https:/github.com/cran/Synth/tree/ master/R [accessed June 1st (2018)].

2 Please see Firpo and Possebom (2017) for the steps on how to construct such CIs.

Abadie, A., \& Gardeazabal, J. (2003). The economic costs of conflict: A case study of the Basque country. American Economic Review, 93(1), 113-132. https://doi.org/10.1257/000282803321455188

Abadie, A., Diamond, A., \& Hainmueller, J. (2010). Synthetic control methods for comparative case studies: Estimating the effect of California's tobacco control program. Journal of the American Statistical Association, 105(490), 493-505. https://doi.org/10.1198/jasa.2009.ap08746 Abadie, A., Diamond, A., \& Hainmueller, J. (2015). Comparative politics and the synthetic control method. American Journal of Political Science, 59(2), 495-510. https://doi.org/10.1111/ajps.12116

Almer, C., \& Winkler, R. (2017). Analyzing the effectiveness of international environmental policies: The case of the Kyoto protocol. Journal of Environmental Economics and Management, 82, 125-151. https://doi.org/ 10.1016/j.jeem.2016.11.003

Altman, D., \& Bland, M. (2011). How to obtain the confidence interval from a P value. Research methods and Reporting. British Medical Journal, 343, 1-2. https://doi.org/10.1136/bmj.d2090

Ando, M., \& Savje, F. (2013). Hypothesis testing with the synthetic control method. Working Paper.

Arencibia P. A., Gómez Loscos, A., \& López, M. (2018). A short-term forecasting model for the Spanish economy: GDP and its demand components. Occasional Papers 1801, Banco de España, Occasional Papers Homepage. https://doi.org/10.2139/ssrn.3118855

Badea, L., Panait, I., Socol, A., \& Moraru, D. (2018). Sentiment, perception and policy determinants of foreign direct investment to European developing countries. Economic Computation and Economic Cybernetics Studies and Research, 52(2), 69-85. https://doi.org/10.24818/18 423264/52.2.18.05

Campo, N., Coricelli, F., \& Moretti, L. (2016). Deep integration and economic growth: Counterfactual evidence from Europe. Presented paper at 22nd Dubrovnik Economic Conference. 
DRUŠ. ISTRAŽ. ZAGREB GOD. 29 (2020), BR. 4, STR. 643-663

ŠKRINJARIĆ, T., ČIŽMEŠIJA, M.: HAS THE ACCESSION...
Chan, H., Frey, B., Gallus, J., \& Torgler, B. (2014). Academic honors and performance. Labour Economics, 31, 188-204. https://doi.org/10.1016/j. labeco.2014.05.005

Čižmešija, M. (2001). Pokazatelji konjunkture u prerađivačkoj industriji, građevinarstvu i trgovini Hrvatske [Business survey indicators in the manufacturing industry, construction and retail trade in Croatia]. In G. Nikić (Ed.), Istraživanje konjunkture u Hrvatskoj. Konjunkturni test/Investicijski test [Investigation of conjuncture in Croatia. Conjuncture test/Investment test] (pp. 32-42). Binoza press.

Čižmešija, M., Erjavec, N., \& Bahovec, V. (2014). The role of business survey measures in forecasting Croatian industrial production. International Journal of Social, Human Science and Engineering, 8(3), 67-72.

Demirel, S., \& Artan, S. (2017). The causality relationships between economic confidence and fundamental macroeconomic indicators: Empirical evidence from selected European Union countries. International Journal of Economics and Financial Issues, 7(5), 417-424.

Duarte, I., Pinho de Mello, J., \& Carrasco, V. (2014). A decada perdida: 2003-2012 [The Lost Decade: 2003-2012]. Texto para Discussao 626 [Discussion text 626]. Department of Economics PUC-Rio (Brazil).

Erjavec, N., Sorić, P., \& Čižmešija, M. (2016). Predicting the probability of recession in Croatia: Is economic sentiment the missing link? Proceedings of Rijeka Faculty of Economics. Journal of Economics and Business, 34(2), 555-579. https://doi.org/10.18045/zbefri.2016.2.555

European Commission (2017). The joint harmonised EU programme of business and consumer surveys, User guide. https://ec.europa.eu/info/ business-economy-euro/indicators-statistics/economic-databases/busi ness-and-consumer-surveys/methodology-business-and-consumersurveys/methodological-guidelines-and-other-documents_en

European Commission (2018). Business and consumer survey database. https://ec.europa.eu/info/business-economy-euro/indicators-statistics/ economic-databases/business-and-consumer-surveys/downloadbusiness-and-consumer-survey-data/time-series_en

Eurostat (2018). http://ec.europa.eu/eurostat/data/database

Ferman, B., \& Pinto, C. (2017a). Placebo tests for synthetic controls. MPRA working papers. https://mpra.ub.uni-muenchen.de/78079/

Ferman, B., \& Pinto, C. (2017b). Revisiting the synthetic control estimator. Textos para discussão 421, FGV/EESP - Escola de Economia de São Paulo, Getulio Vargas Foundation (Brazil).

Ferman, B., Pinto, C., \& Possebom, V. (2017). Cherry picking with synthetic controls. Textos para discussão 420, FGV/EESP - Escola de Economia de São Paulo, Getulio Vargas Foundation (Brazil).

Firpo, S., \& Possebom, V. (2017). Synthetic control method: Inference, sensitivity analysis and confidence set. Working paper. https://doi.org/10. 1515/jci-2016-0026

Galiani, S., \& Quistorff, B. (2017). The synth runner package: Utilities to automate synthetic control estimation using synth. Stata Journal, StataCorp LP 17(4), 834-849. https://doi.org/10.1177/1536867X1801700404 
DRUŠ. ISTRAŽ. ZAGREB GOD. 29 (2020), BR. 4, STR. 643-663

ŠKRINJARIĆ, T., ČIŽMEŠIJA, M. HAS THE ACCESSION...
Gardner, M., \& Altman, D. (1986). Confidence intervals rather than P values: Estimation rather than hypothesis testing. British Medical Journal, 292, 746-750. https://doi.org/10.1136/bmj.292.6522.746

Gayer, C., \& Weiss, P. (2005). Convergence of business cycles in the euro area: Evidence from survey data. Ifo conference on survey data in economics - methodology and applications. Proceedings - Cess IFO, Munich, 14-15 October 2005.

Grgić, M., \& Bilas, V. (2008). International economy (in Croatian). Lares Plus. Gyoerk, E. (2017). Economic costs and benefits of EMU membership from the perspective of a non-member. Open Economies Review, 28, 893-921. https://doi.org/10.1007/s11079-017-9466-8

Hinrichs, P. (2012). The effects of affirmative action bans on college enrolment, educational attainment, and the demographic composition of universities. Review of Economics and Statistics, 94(3), 712-722. https://doi.org/10.1162/REST_a_00170

Imbens, G., \& Rubin, D. (2015). Causal inference for statistics, social, and biomedical sciences: An introduction. Cambridge University Press. https://doi. org/10.1017/CBO9781139025751

Kovačić, Z., \& Vilotić, M. (2017). Assessing European business cycles synchronization. MPRA Paper no. 79990.

König, J. (2015). European integration and the effects of country size on growth. Journal of Economic Integration, 30(3), 501-531. https://doi. org/10.11130/jei.2015.30.3.501

Koukouritakis, M., Papadopoulos, A. P., \& Yannopoulos, A. (2013). Linkages between the Euro zone and the South-Eastern European countries: A global VAR analysis (Working Paper No. 163). Bank of Greece.

Kurnoga Živadinović, N., Dumičić, K., \& Čeh Časni, A. (2009). Cluster and factor analysis of structural economic indicators for selected European countries. WSEAS Transactions on Business and Economics, 6(7), 331-341.

Kurnoga, N., \& Čižmešija, M. (2015). Has the long-term recession changed managers' assessments and expectations in the Croatia's retail trade sector? In L. Zadnik Stirn, J. Žerovnik, M. Kljajić Borštnar, \& S. Drobne (Eds.), Proceedings of the 13th International Symposium on Operational Research SOR '15 (pp. 508-513). Slovenian Society Informatika, Section for Operational Research.

$\mathrm{Li}, \mathrm{Q}$. (2012). Economic consequences of civil wars in the post-World War II period. The Macrotheme Review, 1(1), 50-60.

Nunes, L., Silva, A., \& Dias, A. (2014). Sentiment surveys in Portugal - Description and empirical analysis. Journal of Mathematics and Statistical Science, 4, 137-144.

Ribeiro, F., Stein, G., \& Kang, T. (2013). The Cuban experiment: Measuring the role of the 1959 revolution on economic performance using synthetic control. Working paper.

Simon, A. (2015). The evolution of the savings rate in Europe - Empirical evidences. Theoretical and Applied Economics. Special Issue Volume XXII, 19-26.

Tkacova, A., Sinicakova, M., \& Kralik, A. (2015). Industrial indicators and their influence on the V4 countries business cycles. Aktual'ni Problemy Ekonomiky - Actual Problems in Economics, 164, 169-178. 
DRUŠ. ISTRAŽ. ZAGREB GOD. 29 (2020), BR. 4, STR. 643-663

ŠKRINJARIĆ, T., ČIŽMEŠIJA, M.: HAS THE ACCESSION..
Tomić, D., \& Demanuele, D. (2017). Synchronicity and similarity of business cycles; Croatia vis À vis new EMU countries. Review of Innovation and Competitiveness, 3(4), 31-56. https://doi.org/10.32728/ric.2018.34/2

World Bank (2016). Classification of countries by income. http://go.world bank.org/L547EEP5C0

Yu, J., \& Wang, C. (2013). Political risk and economic development: A case study of China. Economic Research 26(2), 35-50. https://doi.org/ 10.1080/1331677X.2013.11517605

Verdict (2018). EU Brexit sentiment: Europeans increasingly positive about EU membership. https://www.verdict.co.uk/eu-brexit-sentiment/

Žudel, B., \& Melioris, L. (2016). Five years in a balloon: Estimating the effects of Euro adoption in Slovakia using the synthetic control method. Economics department working papers No. 1317, ECO/WKP((2016))41.

\section{Je li ulazak Hrvatske u Europsku uniju utjecao na poslovni sentiment $u$ industriii? Pristup metode sintetičke kontrole}

Tihana ŠKRINJARIĆ, Mirjana ČIŽMEŠIJA

Sveučilište u Zagrebu, Ekonomski fakultet, Zagreb, Hrvatska

Određeni ekonomski i politički događaji određuju razinu i dinamiku kretanja realnih ekonomskih varijabli, s jedne strane, dok s druge strane poslovni sentiment kao "soff" varijabla ima dobru prediktivnu moć tih istih varijabli. U ovom radu razmatramo učinak ulaska Hrvatske u Europsku uniju (EU) 2013. godine na Pokazateli konjunkturne klime $u$ industriii $(\mathrm{ICl})$ kao mjeru poslovnoga sentimenta u hrvatskoj industriii. Ulazak u EU imao je snažan pozitivan utjecaj na ekonomije koje su ušle u Uniju. Za razliku od drugih novih država članica EU-a, koje su ušle u EU u uzlaznoj fazi europskoga poslovnog ciklusa, Hrvatska je u ovu zajednicu ušla odmah nakon stabilizacije europske dužničke krize i u dugoj recesiii. Primienom novoga pristupa metode sintetičke kontrole (SCM) nad podacima anketa pouzdanja poduzeća (BS), potvrđena je glavna hipoteza rada da je ulazak Hrvatske u EU imao jak pozitivan učinak na $\mathrm{ICl}$, što se može objasniti kao euforija. Zaključci utemeljeni na rezultatima ovog istraživanja služe pobolišanju i popularizaciji BS i SCM.

Ključne riječi: indikator industrijske proizvodnje, metoda sintetičke kontrole, poslovne i potrošačke ankete, protučinjenična metodologija

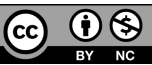

Međunarodna licenca / International License: 